\title{
ETIKA PUBLIK BAGI KEPEMIMPINAN PEMERINTAH DAERAH
}

\author{
Rumsari Hadi Sumarto \\ Akademi Sekretari dan Manajemen Indonesia Desanta, Yogyakarta \\ Email: hrumsari@yahoo.com
}

\begin{abstract}
Ethics has always been a part of human life in which ethics as a guide to judge the good of an action. Ethics is actually very close to one's life including public leaders. If the public leader always presents ethics in every action, then the public leader will be able to minimize actions that conflict with ethical values, including in cases of corruption. Ethical values that should be used as guidance for public leaders, especially the head of the region seems to lose its meaning when the head of the region committed ethical violations such as corruption cases. Therefore, it is important to understand that public ethics can fortify regional heads to keep acting in accordance with prevailing norms and not to deny public ethics. Public ethics that always be the basis of behavior of the head of the region will bring to the head of the region that is able to represent itself as a person who has personal integrity and can be an example for the bureaucratic apparatus and society in a region.
\end{abstract}

Key words: Public Ethics, Local Government Leadership, Integrity

\section{PENDAHULUAN}

\section{Latarbelakang}

Pada saat ini kasus-kasus yang menyangkut semakin tergerusnya etika dari pemimpin publik semakin mengemuka dan bahkan beberapa pejabat publik yang melakukan pelanggaran etika tersebut seolaholah menganggap kasus tersebut bukan suatu kejadian yang luar biasa dan dilakukan juga oleh pemimpin publik lainnya. Pelanggaran etika yang terjadi dari pemimpin publik lebih banyak didominasi oleh kasus korupsi. Dari tahun ke tahun wajah pemimpin publik seperti gubernur, bupati, walikota yang tersangkut korupsi dengan berbagai macam kasus semakin marak menghiasi headline di media cetak dan elektronik. Terlepas dari opini yang menggiring bahwa kasus korupsi yang dituduhkan kepada seorang pemimpin publik sering dikaitkan dengan rekayasa politik, tetapi realitanya pemimpin publik tersebut khususnya kepala daerah mayoritas masuk dalam OTT dari KPK dengan buktibukti yang sudah dipegang oleh KPK.

Pada tahun 2017 saja, hingga bulan September sudah 5 Kepala Daerah yang terjerat kasus korupsi, diantaranya adalah Gubernur Bengkulu, Ridwan atas dugaan suap pada proyek peningkatan jalan TESMuara Aman dan proyek peningkatan jalan Curug Air Dingin Kabupaten Rejang Lebong. Dalam kasus ini, Ridwan diduga mendapat commitment fee Rp 4,7 miliar dari proyek itu. Kemudian Bupati Pamekasan Achmad Syafii sebagai tersangka pada Rabu (2/8/2017) dalam kasus dugaan suap untuk menghentikan penanganan kasus korupsi penyelewengan dana desa. Selain Achmad, KPK menetapkan empat orang lainnya sebagai tersangka yakni Kepala Kejaksaan Negeri Pamekasan Rudi Indra Prasetya, Kepala Inspektorat Kabupaten Pamekasan, Sucipto Utomo, Kepala Desa Dasuk Agus Mulyadi, dan Kepala Bagian Administrasi Volume 2, Nomor 2, Oktober 2017 112 | PUBLISIA (Jurnal Ilmu Administrasi Publik) 
Inspektorat Kabupaten Pamekasan Noer Solehhoddin. Pada tahun yang sama Tim KPK menangkap Wali Kota Tegal Siti Masitha Soeparno pada Selasa (29/8/2017) di Rumah Dinas Wali Kota di Kompleks Balai Kota, Kota Tegal bersama dua orang lainnya yakni Ketua DPD Partai Nasdem Brebes Amir Mirza Hutagalung dan Wakil Direktur RSUD Kardinah Cahyo Supriadi. Walikota Tegal ditetapkan sebagai tersangka kasus dugaan suap pengelolaan dana jasa pelayanan RSUD Kardinah Kota Tegal Tahun 2017 dan pengadaan barang dan jasa di lingkungan Kota Tegal tahun 2017. Siti diduga menerima suap Rp 5,1 miliar. Kemudian KPK menetapkan Bupati Batubara OK Arya Zulkarnaen sebagai tersangka pada Kamis (14/9/2017), pasca-operasi tangkap tangan yang dilakukan sehari sebelumnya. Dalam kasus ini, selain Bupati OK Arya, empat orang lainnya yakni Kadis Pekerjaan Umum dan Penataan Ruang (PUPR) Helman Herdady, seorang pemilik dealer mobil Sujendi Tarsono alias Ayen, dua orang kontraktor bernama Maringan Situmorang dan Syaiful Azhar, turut ditetapkan sebagai tersangka. OK Arya menjadi tersangka kasus suap pengerjaan pembangunan infrastruktur di Kabupaten Batubara tahun 2017. Ia diduga menerima fee Rp 4,4 miliar dari tiga proyek pembangunan jembatan. Pada bulan September 2017, Wali Kota Batu Eddy Rumpoko ditetapkan sebagai tersangka pada Minggu (18/9/2017) pasca operasi tangkap oleh tim KPK di rumah dinasnya sehari sebelumnya. Ia menjadi tersangka dugaan suap proyek belanja modal dan mesin pengadaan meubelair di Pemkot Batu tahun anggaran 2017 senilai Rp 5,26 miliar, yang dimenangkan PT Dailbana
Prima. Dalam kasus ini, Eddy Rumpoko diduga menerima suap Rp 500 juta atau sekitar 10 persen dari nilai proyek. http://nasional.kompas.com/read/2017/09/19/0700 0031/hingga-september-2017-5-kepala-daerahterjaring-ott-kpk-siapa-saja-mereka?page=all

Dengan terpaparnya beberapa kasus korupsi tersebut, maka perlu dipertanyakan tentang makna dan realisasi etika bagi para pemimpin publik khususnya kepala daerah. Integritas pemimpin publik sering dipertanyakan pada saat pemimpin publik tersebut terjerat dalam kasus pelanggaran etika publik. Sebagai pemimpin di suatu daerah, para pemimpin publik menjadi cerminan baik bagi aparat birokrasi dan bagi masyarakat di daerah tersebut. Masyarakat tentunya menginginkan kepala daerah mereka merupakan sosok yang 'bersih' dan dapat menjadi teladan bagi masyarakat di daerah tersebut. Dengan demikian, penghayatan akan etika publik harus benarbenar menjadi bagian yang tidak terpisahkan dari sosok kepala daerah bahkan menjadikan acuan atau landasan bagi pemimpin publik dalam berperilaku dan memimpin suatu pemerintah daerah.

\section{Tujuan Penulisan}

Adapun tujuan penulisan mengenai Etika Publik bagi Kepemimpinan Pemerintah Daerah adalah mendeskripsikan dan menganalisis ha-hal yang berkenaan dengan etika publik bagi Kepala Daerah baik Gubernur, Bupati dan Walikota. Etika publik seyogyanya menjadi dasar perilaku kepala daerah sehingga kepala daerah mampu menghadirkan sosok yang memiliki integritas 
tinggi dan dapat menjadi teladan bagi aparat publik dan masyarakat.

\section{KAJIAN PUSTAKA \\ Etika Publik}

Etika selalu hadir pada setiap sisi kehidupan seseorang dan organisasi. Bahkan dari usia dini hingga lanjut usia selalu diperhadapkan bagaimana hidup yang selaras dengan etika terlebih bila orang tersebut berada di tengah-tengah komunitas. Bila etika dilanggar oleh seseorang atau organisasi, maka sanksi sosial dan hukum biasanya dikenakan pada pemimpin publik yang melakukan pelanggaran etis tersebut.

Menurut Haryatmoko, etika lebih dipahami sebagai refleksi atas baik atau buruk, benar atau salah yang harus dilakukan atau bagaimana melakukan yang baik atau benar (2011: 2). Sedang menurut Bertens, etika berarti moral. Etika menyangkut suatu perbuatan boleh dilakukan atau tidak. Etika tidak tergantung pada hadir tidaknya orang lain. Etika jauh bersikap absolut (2013: 8). Etika membawa manusia untuk berpikir dan bertindak lebih hati-hati dengan mempertimbangkan sisi baik dan buruk dari tindakan yang dilakukan. Etika dikatakan absolut dalam arti bahwa etika tidak memberi ruang untuk direduksi pemaknaannya dari suatu tindakan yang dilakukan. Dengan lebih mengedepankan sisi baik, maka seseorang dapat melakukan tindakan yang etis sehingga tidak merugikan pihak lain. Ditegaskan oleh Praja bahwa etika mempunyai sifat yang mendasar yaitu sifat kritis. Etika menuntut agar orang bersikap rasional terhadap norma (2003: 59). Sifat rasional dari seseorang akan membimbing seseorang mengedepankan norma-norma yang ada sehingga orang tersebut akan bersikap kritis untuk setiap tindakan yang dilakukan. Dalam hal ini orang akan mempertimbangkan secara matang apakah tindakannya akan merugikan atau menguntungkan orang lain. Apabila etika dijadikan landasan untuk bertindak, maka orang tersebut akan memilih langkah yang tidak merugikan pihak lain. Dengan demikian, etika bukan merupakan sesuatu yang abstrak dan dapat dirasionalkan sehingga pada dasarnya mudah untuk dilakukan tetapi dapat dianggap rumit karena seseorang melakukan penawaran lain yang lebih menguntungkan dirinya sekalipun harus merugikan orang lain.

Di dalam etika biasanya dikenal dengan hati nurani. Menurut Bertens, hati nurani adalah instansi dalam diri manusia yang menilai tentang moralitas perbuatan manusia. Tidak mengikuti hati nurani berarti menghancurkan integritas pribadi dan mengkhianati martabat terdalam manusia (2013: 41). Dapat dikatakan juga bahwa hati nurani adalah kesadaran moral, instansi yang membuat seseorang menyadari yang baik atau yang buruk (secara moral) dalam perilaku seseorang (Bertens 2013: 41). Dengan adanya hati nurani dalam diri seseorang, maka orang tersebut seolah-olah mendapat tuntunan dari dalam dirinya yang menilai suatu perbuatan itu layak atau tidak layak untuk dilakukan. Apabila tuntunan di dalam berhasil mengarahkan kepada hal yang positif, maka akan memberi dampak positif pada perilaku orang tersebut. Orang tersebut mampu menjaga dan mempertahankan integritas dirinya dan tidak mencederai martabat terdalam manusia. Misalnya dalam 
konteks korupsi, bila hati nurani menuntun ke arah yang positif bahwa korupsi mencederai integritas pribadi dan merugikan pihak lain, maka sebenarnya orang tersebut akan membentengi dirinya untuk tidak melakukan korupsi. Oleh karena itu, pemahaman akan hati nurani yang benar akan membawa seseorang untuk menerapkan prinsip-prinsip etika dengan benar terlebih etika publik bagi pemimpin publik khususnya kepala daerah yang sering menjadi sosok sentral dan berpengaruh di suatu daerah.

Etika publik menekankan pada standar untuk menentukan suatu tindakan baik atau buruk di dalam ranah pelayanan publik. Menurut Haryatmoko, etika publik bertujuan menjamin integritas pejabat dalam pelayanan publik (2011: 8). Ditambahkan pula oleh Haryatmoko bahwa etika publik menuntut tiga kompetensi pejabat publik yaitu kompetensi teknis, kompetensi etika dan kompetensi leadership (2011: 20). Apabila etika publik dihayati oleh setiap pemimpin publik dalam hal ini kepala daerah, maka kasus pelanggaran etika seperti korupsi setidaknya dapat diminimalir bahkan tidak akan dilakukan oleh kepala daerah. Seyogyanya kompetensi etika yang ada dalam etika publik menjadi tuntunan bagi pemimpin publik atau kepala daerah khususnya sehingga integritas kepala daerah tetap terjaga di samping kompetensi teknis yang harus dimiliki seorang kepala daerah.

\section{Kepemimpinan Publik}

Sebelum berbicara mengenai kepemimpinan publik biasanya sosok pemimpin menjadi pendahulu untuk lebih memperjelas tentang konsep kepemimpinan.
Pemimpin menurut Syafii adalah orang yang mempengaruhi pihak lain melalui proses kewibawaan komunikasi sehingga orang lain tersebut bertindak sesuatu dalam mencapai tujuan tertentu (2013: 132). Seorang pemimpin dapat mempengaruhi orang lain sehingga orang lain akan melakukan tindakan sesuai yang diinginkan pemimpin tersebut dalam rangka pencapaian suatu tujuan. Ordway Tead mengemukakan sifat-sifat pemimpin adalah energi jasmani dan rohani, kepastian akan maksud dan tujuan, entusiasme, ramah, penuh persahabatan dan tulus, integritas (pribadi yang bulat), kecakapan teknik, mudah menatapkan keputusan, cerdas, cakap mengajar, keyakinan (Pamudji 1993: 74 -75). Sifat-sifat pemimpin tidak jauh dari integritas seseorang dan sifat tersebut akan membawa pemimpin mempengaruhi orang lain atau kelompok dengan energi yang positif.

Dikatakan oleh Sedarmayanti bahwa pemimpin bangsa abad 21 harus memiliki minimal beberapa kemampuan kompetensi diantaranya adalah kemampuan pribadi yang meliputi memiliki integritas tinggi (jujur, loyal, beriman), memiliki visi yang jelas, intelegensia tinggi kreatif dan inovatif, tidak mudah puas, fleksibel dan memiliki kematangan jiwa, sehat jasmani dan rohani, memiliki wawasan dan kharismatik, mempunyai idealisme dan cinta tanah air (2009: 142 - 143). Setangguh dan secerdas apapun seorang pemimpin tetapi pemimpin tersebut tetap harus memiliki integritas yang tinggi sehingga kemampuan dan kecerdasan yang dimiliki tidak disalahgunakan untuk memanipulasi setiap tindakan yang dilakukan. Terlebih kepemimpinan publik 
atau kepemimpinan pemerintahan khususnya pemerintah daerah harus mampu merepresentasikan dirinya sebagai sosok yang cerdas sekaligus memiliki kepribadian yang menjunjung tinggi nilai-nilai etis. Integritas dirinya tidak akan dipertaruhkan untuk melakukan tindakan yang bertentangan dengan nilai-nilai etika publik yang berlaku.

Menurut Sedarmayanti, saat ini banyak pihak yang mendambakan pemimpin yang mampu membawa ke arah yang lebih baik, mendambakan pemimpin sejati, yang mampu menghadirkan visi, mengintegrasikan makna hidup di dalamnya dan perilaku lain yang dibangun berdasar prinsip dan etika universal yang menguntungkan masyarakat (2009: 201 202). Ekspetasi dari masyarakat atau siapapun sangat mendasar yaitu memiliki sosok pemimpin publik yang berintegritas. Mengintegrasikan makna hidup dalam perilakunya yang dibangun berdasar prinsip dan etika universal kiranya menjadi landasan kuat bagi pemimpin publik untuk bertindak. Segala tindakan bila dilandasi oleh perilaku etis akan memberi dampak positif bagi aparat birokrasi dan masyarakat di daerah tersebut.

Pemimpin adalah orangnya, sedang kepemimpinan menurut Sedarmayanti adalah seni mempengaruhi dan mengarahkan orang dengan cara kepatuhan, kepercayaan, kehormatan dan kerja sama yang bersemangat dalam mencapai tujuan bersama (2009: 121). Sedang kepemimpinan birokrasi adalah kemampuan mempengaruhi dan memberikan motivasi kepada bawahan yang berdampak kepada meningkatnya kinerja pegawai yang dipimpinnya (Pasolong 2013: 118). Dengan demikian, kepemimpinan birokrasi atau kepemimpinan publik merupakan kemampuan seorang pemimpin publik untuk mempengaruhi aparat birokrasi dan memotivasi mereka untuk meningkatkan kinerjanya agar penyelenggaraan pelayanan publik dapat menjadi lebih optimal.

Disebutkan oleh Kaloh bahwa salah satu karakteristik kepemimpinan pemerintahan, khususnya kepala daerah adalah tanggap terhadap kondisi politik, baik dalam organisasi pemerintahan maupun dalam masyarakat, serta memberikan jawaban atau tanggapan atas kritik, saran dan mungkin juga pengawasan yang datangnya dari masyarakat, serta tanggap terhadap harapan dan kebutuhan masyarakat (2014: 5 - 6). Ditambahkan oleh Kaloh bahwa keadaan dan tantangan yang dihadapi oleh kepala daerah antara lain bagaimana mewujudkan otonomi luas, nyata dan bertanggung jawab yang didukung oleh kualitas sumber daya aparatur yang prima, sumber alam dan sumber keuangan serta sarana dan prasarana yang memadai, yang mampu meningkatkan dan mengembangkan kemampuan dan kehidupan masyarakat melalui program dan trategi pelayanan dan pemberdayaan (2014: 6). Karakteristik kepemimpinan publik khususnya kepala daerah harus fokus untuk mengembangkan organisasi pemerintahan agar semakin berdaya guna dalam melayani kepentingan publik, tanggap dan peka terhadap apa yang menjadi ekspetasi masyarakat di daerah tersebut. Dengan demikian, pada dasarnya tidak mudah menjadi pemimpin publik khususnya kepala daerah mengingat tugas dan tanggung jawabnya luas baik fokus ke dalam organisasi publik itu sendiri maupun kepada masyarakat. Untuk itu dibutuhkan pemimpin 
publik dalam hal ini kepala daerah yang memiliki kredibilitas dan integritas yang tinggi untuk mengemban tugas dan tanggung jawab tersebut.

Bahkan Kartasasmita menyatakan bahwa kepemimpinan sangat penting dan amat menentukan dalam kehidupan setiap bangsa karena maju mundurnya masyarakat, jatuh bangunnya bangsa ditentukan oleh pemimpinnya (Pasolong 2013: 18). Kepemimpinan publik khususnya kepala daerah menjadi penentu keberhasilan pembangunan di daerahnya dan penentu keberhasilan dalam memotivasi dan menggerakkan bawawahannya agar memiliki jiwa pelayanan sehingga mampu melayani masyarakat dengan baik. Keberhasilan tersebut tidak lepas juga dari sosok pemimpin publik atau kepala daerah yang melandasi etika universal dalam setiap perilakunya. Terlebih saat ini konsep tentang kepemimpinan pelayan selalu menjadi wacana yang selalu dibangun dan diopinikan sehingga sosok pemimpin publik yang memiliki integritas yang tinggi sangat dibutuhkan. Pasolong mengatakan bahwa karakteristik kepemimpinan pelayan adalah mendengarkan, empati, menyembuhkan, kesadaran diri, persuasif, konseptualisasi, kemampuan untuk melihat masa depan, kemampuan melayani, komitmen pada pertumbuhan individu dan membangun komunitas (2013: 66). Kemampuan melayani harus didasarkan pemahaman bahwa kepentingan pribadi tidak boleh di atas kepentingan publik. Dengan demikian, tindakan melakukan korupsi yang sarat dengan kepentingan pribadi tidak dapat dibenarkan untuk sosok pemimpin pelayan terutama kepala daerah yang mengelola pemerintah daerah dan melayani masyarakat di daerah tersebut.

\section{IMPLEMENTASI ETIKA PUBLIK PADA KEPEMIMPINAN PEMERINTAH DAERAH}

Kepemimpinan publik atau kepemimpinan pemerintah daerah khususnya yang meletakkan perilaku etis menjadi begitu penting untuk selalu diwacanakan mengingat banyaknya pemimpin publik khususnya Kepala Daerah yang tersangkut kasus pelanggaran etika publik dalam memimpin dan mengelola daerahnya. Pelanggaran etika publik yang dominan dilakukan oleh pemimpin publik adalah kasus korupsi.

Haryatmoko mengatakan bahwa korupsi yang sudah mengakar membuat tugas etika publik untuk membangun integritas pejabat publik menjadi semakin tidak mudah. Membangun integritas tidak cukup hanya mengandalkan kualitas moral seseorang tetapi dengan membangun budaya etika organisasi (2011: 31). Jelas bahwa korupsi yang sudah mengakar akan sulit untuk diurai dan diluruskan terlebih bila korupsi dilakukan secara sistemik. Budaya etika organisasi harus dijadikan landasan perilaku bagi siapapun sehingga korupsi tidak akan menjadi kebiasan yang merambah ke setiap jenjang struktur organisasi pemerintah. Tentu saja sosok pemimpin publik harus kuat dalam mengusung dan melembagakan budaya etika organisasi kepada anggotanya.

Menurut Haryatmoko, korupsi mengkomunikasikan praktik pelaksanaan kekuasaan seperti cara membuat laporan, cara berinteraksi dengan atas dan instansi lain, cara kontrak, cara membuat anggaran, cara 
mendapat jabatan, cara penempatan anak buah, cara perekrutan karyawan, syarat urusan bisa beres (2011: 28). Dalam hal ini berarti bahwa korupsi dapat dilakukan dalam setiap urusan atau kegiatan dengan mencari celah untuk melakukan tindakan yang sebenarnya mengingkari hati nurani. Misalnya bagaimana seseorang pejabat publik menyusun anggaran dengan melakukan mark up sehingga tidak sesuai dengan harga kewajaran. Bagaimana seseorang ingin mendapatkan jabatan tertentu, maka pejabat diatasnya memberi celah dengan menawarkan suatu 'harga' atas suatu jabatan tertentu.

Menurut London, penyalahgunaan yang dilakukan tidak hanya didefinisikan dari sudut pandang hukum, tetapi juga harus diperhitungkan pemaknaan sosial dan standar budaya, artinya korupsi menggerogoti nilainilai kepemimpinan, kewarganegaraan, representasi, deliberasi dan akuntabilitas (Haryatmoko 2011: 29). Dengan demikian, korupsi tidak dipandang berdampak pada sudut pandang hukum tetapi juga dipertimbangkan pada dampak terhadap nilai-nilai sosial, budaya dan nilai-nilai kepemimpinan yang lebih dalam maknanya. Dalam hal ini hukuman tidak akan berhasil memberhentikan seseorang untuk menghindari dari tindakan korupsi bila orang tersebut tidak menanamkan nilai-nilai tersebut secara mendalam dan terrepresentasi dalam setiap perilakunya. Bahkan akan lebih memprihatinkan bila hasil tindakan korupsi dimanipulasi untuk manifestasi kegiatan sosial atau lebih dikenal dengan impunity. Menurut Haryatmoko, impunity menjadi salah satu sebab mewabahnya korupsi dan tiadanya rasa bersalah yaitu mengurangi rasa bersalah atau menghapus jejak kejahatan dengan menyumbangkan uang untuk pembangunan rumah ibadah, lembaga agama atau ke bentuk kesalehan lain (2011: 28). Dengan label peduli terhadap kegiatan sosial, maka hal yang dilakukan tersebut seolah-olah menjustifikasi bahwa melakukan korupsi tidak menjadi masalah bila dimanifestasikan dalam bentuk sumbangan ke kegiatan agama dan kegiatan sosial lainnya. Tentu saja hal ini sangat bertentangan dengan nilai-nilai etis yang tidak memberi ruang sedikitpun untuk membenarkan bahwa tindakan korupsi diperbolehkan bila hasil korupsi tersebut dihibahkan untuk kegiatan sosial.

Menurut Haryatmoko, apa yang dipertaruhkan dalam habitat buruk korupsi adalah pembentukan mental bangsa (mental menerabas), egoisme, tak peduli kesejahteraan bersama, tidak peka terhadap ketidakadilan, redupnya solidaritas (2011: 28). Apapun argumen yang ingin membenarkan tindakan korupsi tetap bertentangan dengan nilai-nilai etis bahkan akan menjadikan pelemahan mental bangsa dan mereduksi konsep keadilan.

Dijelaskan oleh Haryatmoko bahwa etika publik berupaya mengelaborasi agar norma etika semakin tercermin dalam regulasi pelayanan publik (2011: 31). Organisasi publik tidak lain dibentuk dalam rangka memberikan pelayanan publik sehingga publik dapat mengakses layanan publik dengan cara yang cepat, mudah dan selaras dengan norma yang berlaku. Dengan demikian, apabila di dalam pelayanan publik masyarakat dihadapkan pada situasi bahwa untuk mempercepat pelayanan ada harga 
tertentu yang harus dibayar, maka etika publik tidak hadir dalam pelayanan tersebut.

Adapun tujuan etika publik menurut Haryatmoko adalah ingin menjamin agar ada integritas organisasi atau badan pemerintah, yang dimulai dengan integritas pejabat publik yang tepat janji (2011: 35). Integritas pejabat publik menjadi penting sebagai landasan integritas organisasi. Dengan demikian, seseorang harus menjaga integritas dirinya agar mampu menghadirkan sosok yang positif dan dapat menjadi teladan bagi orang lain. Terlebih bila sosok tersebut merupakan pejabat publik, maka intergritas sebagai pejabat publik layak untuk dipegang teguh dan dipertahankan.

Menurut Haryatmoko, integritas publik merupakan kualitas perilaku seseorang atau organisasi yang sesuai dengan nilai-nilai, standar dan aturan moral yang diterima oleh anggota organisasi dan masyarakat (2011: 72). Pejabat publik dalam hal ini kepala daerah sangat perlu menjaga integritasnya karena yang dihadapi tidak hanya bawahan di lingkungan organisasi publik tetapi juga berhadapan dengan masyarakat yang sering memberi penilaian atas perilakunya sebagai kepala daerah. Ditambahkan oleh Haryatmoko, bahwa integritas publik baru kelihatan ketika harus berhadapan dengan kebijakan publik yang menyangkut pengelolaan kekayaan negara. Integritas publik berkaitan erat dengan penggunaan sumber dana, sumber daya, aset dan kekuasaan yang sesuai dengan tujuan jabatan publik untuk digunakan dalam meningkatkan pelayanan publik (2011: 73). Bahkan integritas publik akan teruji ketika pejabat publik dihadapkan pada pilihan-pilihan kewajiban yang saling bertentangan, tetapi mampu memberi pemecahan dengan mengesampingkan kepentingan pribadi atau kelompok (Haryatmoko 2011: 73). Integritas memang akan diuji saat pejabat publik dihadapkan pada situasi penggunaan sumbersumber yang ditujukan untuk pelayanan publik, pertentangan di dalam hati nurani akan semakin kuat bila harus mempertimbangkan antara kepentingan pribadi dan kepentingan publik. Bila kepentingan pribadi lebih dominan, maka jalan untuk melakukan tindakan korupsi akan semakin kuat. Logika-logika untuk membenarkan tindakan korupsi dapat dibangun dengan mencari celah di mana tindakan tersebut dapat dilakukan.

Dengan demikian, nilai-nilai etis selayaknya dijaga dan dipertahankan oleh pejabat publik agar integritas tetap terjaga saat suatu situasi dan keadaan menguji integritas pribadi seorang pejabat publik atau kepala daerah. Hal yang mendasar mengapa perlunya integritas pada sosok kepala daerah bahwa kepala daerah harus menjadi 'teladan' baik bagi bawahannya dan masyarakat. Syafii menegaskan bahwa salah satu teknik kepemimpinan pemerintahan Indonesia adalah teknik keteladanan (2013: 159 -160). Keteladanan kepala daerah yang memiliki integritas tinggi dan mampu menghayati dan mendasari setiap tindakannya dalam ranah etika publik akan menjadi barometer bagi bawahan dan masyarakat untuk bertindak seperti kepala daerah tersebut.

Dengan demikian, kepala daerah tidak akan melakukan tindakan korupsi karena tindakan tersebut jelas bertentangan dengan etika publik dan mencederai integritas 
dirinya. Masyarakat akan sulit membangun kepercayaan kembali kepada kepala daerah yang telah melanggar etika publik. Dengan demikian, sudah selayaknya setiap kepala daerah harus menjaga dirinya dengan membetengi diri melalui etika publik agar dapat terhindar dari perilaku yang melanggar etika publik dan mampu membawakan dirinya sebagai sosok kepala daerah yang patut diakui integritas dirinya

\section{KESIMPULAN}

Kasus korupsi yang marak terjadi di Indonesia mulai dari pusat hingga daerah telah menjadi konsumsi bangsa Indonesia dengan terjeratnya beberapa pejabat publik dan khususnya kepala daerah pada kasus korupsi. Korupsi yang marak dilakukan oleh kepala daerah terjadi karena beberapa kepala daerah menafikan etika publik yang seharusnya menjadi dasar segala perilaku dari kepala daerah. Etika publik yang menuntun kepala daerah untuk selalu mempertimbangkan baik dan buruknya suatu tindakan yang akan dilakukkan sebenarnya sangat relevan bagi kepala daerah untuk tidak terseret kasus korupsi. Namun kenyataannya banyak kepala daerah yang tidak dapat menghindar untuk masuk dalam lingkaran kasus korupsi.

Oleh karena itu, etika publik seyogyanya benar-benar menjadi pegangan bagi kepala daerah dalam mengelola organisasi publik yang dipimpinnya agar pelayanan publik dapat terealisir dengan baik dan etis. Etika publik yang menjadi dasar dalam setiap langkah dan tindakan kepala daerah akan semakin menguatkan dirinya sebagai sosok yang memiliki integritas tinggi dan dapat menjadi teladan bagi aparat pelayan publik dan masyarakat di daerah tersebut.

\section{DAFTAR PUSTAKA}

Bertens, K., 2013, Etika, Edisi Revisi, Yogyakarta: Kanisius

Haryatmoko, 2011, Etika Publik, untuk Integritas Pejabat Publik dan Politisi, Jakarta: Gramedia Pustaka Utama

Pamudji, S., 1993, Kepemimpinan Pemerintahan di Indonesia, Jakarta: Bumi Aksara

Pasolong, Harbani, 2013, Kepemimpinan Birokrasi, Bandung: Alfabeta

Praja, Juhaya S., 2003, Aliran-aliran Filsafat dan Etika, Jakarta: Kencana Prenadamedia,

Sedarmayanti, 2009, Reformasi Administrasi Publik, Reformasi Birokrasi dan Kepemimpinan Masa Depan, Bandung: Refika Aditama

Syafii, Inu Kencana, 2013, Sistem Administrasi Negara Republik Indonesia, Jakarta: Bumi Aksara

Kaloh, J., 2014, Kepemimpinan Kepala Daerah, Pola Kegiatan, Kekuasaan dan Perilaku Kepala Daerah dalam Pelaksanaan Otonomi Daerah, Jakarta: Sinar Grafika http://nasional.kompas.com/read/2017/09/19/0700 0031/hingga-september-2017-5-kepaladaerah-terjaring-ott-kpk-siapa-sajamereka?page $=$ all 